\title{
THE PAST AND PRESENT OF THE TRANSYLVANIAN SALT WATERS
}

\author{
BOGLÁRKA CZELLECZ1 ${ }^{\text {, NOÉMI-MÁRIA SZOPOS }}{ }^{1}$
}

\begin{abstract}
The Past and Present of the Transylvanian Salt Waters. The Transylvanian salt was always in the center of attention from different points of view during different periods. In the past centuries, identifying the location and extent of this resource was the most important issue, since mining and trading were top priority activities. In recent times the formation of the salt deposits is mostly in the attention of the scientists, so salt is a subject of a continuous interest. Waters that get their mineralization by interacting with the salt beds have been less researched. They were in the center of attention mostly in the second part of the $19^{\text {th }}$ century, while in the recent times just a few studies have dealt with this topic. Field observations carried out in 2016 revealed that the number of salt water occurrences at surface decreased over time. By exploring the causes why these sources have disappeared, we succeeded to gather valuable information about the appreciation of the salt waters during the centuries. Until the $14^{\text {th }}$ century all salt products were considered as part of the land, while in the late Middle Ages this perception was replaced with the practice of regalia, the exclusive right of the king over all the salt resources, including the salt waters. The rights that the regalia empowered the kings were not equally applied over time. The most rigurous actions to protect the rights over this resource were applied during the $19^{\text {th }}$ century. This study presents the legal background and regulation of usage of the salt waters in Transylvania from the Middle Ages until the $20^{\text {th }}$ century. A case study is also presented in order to illustrate the rate of disappearance and present situation of the salt sites in the area South of Cluj-Napoca city.
\end{abstract}

Keywords: salt water, Transylvania, regulation, restriction of usage, present situation.

\section{INTRODUCTION}

As it was a valuable product all over Europe, the Transylvanian salt was mentioned in the international literature published in the previous centuries, but it was only tangentially discussed in those works with even less data about the salt springs that were to be found here.

${ }^{1}$ Babeș-Bolyai University, Faculty of Geography, 400006, Cluj-Napoca, Romania, e-mail: boglarka.czellecz@gmail.com 
The former importance of the Transylvanian salt (in any form) is underlined in the pages of the first scientific journal published in the world - Philosophical Transactions, in its second volume. With the purpose of establishing commercial relations, it was required by the English authorities in 1666 to conduct studies concerning several products/goods available in certain countries, mostly in Europe including Hungary and Transylvania as well $(* * *, 1666)$. England showed interest for the Transylvanian minerals, metals, springs, warm baths, etc. Among others it was required to make reports about the salt pits and the situation of the salt mines (Henshaw, Hill, 1666). Dr. Edward Brown, the person entrusted with performing the survey of the country, reported the mines of Dej, Turda, Cojocna, Sic and Ocna Sibiului in Transylvania. The Transylvanian salt was commercialized on the area between Belgrade and Bratislava; it was forbidden to enter it into Austria. As the result of his investigation only two salt mines were presented in detail in the former Hungary, while the Transylvanian sites were not detailed in his article (Brown, 1670).

Even in the local literature the status of salt springs can be followed only at larger intervals back to the 18th century. Beside the detailed descriptions of the salt rock and salt mines, the literature gives scanty information about the salt springs. It is obvious that the focus was on the salt productions sites, since commercializing the salt products represented a great percent of the state revenue. The salt springs got importance when the regulation of usage of any kind of salt started to become more and more rigorous. The first comprehensive work with the topic of rock salt, all the activities related to it and chapters dedicated to salt springs was published by J. E. Fichtel in 1780 . The work entitled "Geschichte des Steinsalzes und der Steinsalzgruben im Grossfürstenthum Siebenbürgen" was so detailed from many points of view (geology, mining, hydrogeochemistry, transport, regulation), that it was cited for a long time in the national and international literature. The most important works published after Fichtel's book, where salt waters were also discussed, are the following: Beudant (1822), Benigni von Mildenberg (1837), Czekelius (1854), Hunfalvy (1864), Bernáth (1880) and Fischer (1887). Among these writings, full mapping of the springs and wells was performed by Fichtel, Czekelius, Bernáth and Fischer.

Depreciation of the natural occurring salt water resources in many places (but not everywhere) has started in the mid $20^{\text {th }}$ century until today and reached a total loss of care at some places. 


\section{REGULATIONS AND LAWS CONCERNING THE SALT SPRINGS AND WELLS}

The mining of salt and its trade, including from the Transylvanian sites, was one of the most stable and profitable sources of the Hungarian royal incomes. The right of the kings over the salt resources can be interpreted from two points of view: (1) the salt as part of the land, the owner of the land has the right over all resources that can be found on the property, (2) the salt as a regalia, the exclusive right or possession of the king over the resource itself including all the mining and commercial activities.

\subsection{The salt becoming a regalia - how the salt resources were treated during the Hungarian kings}

From charters, as certified sources, it is already known that during the Árpád dynasty (the first kings of the Kingdom of Hungary after the foundation of the state in $1000 \mathrm{AD}$ ) the right of operation of salt mines was based on the ownership of the land. The reason why it was hard to separate this kind of operation from the era of the regalia is that most of the salt-bearing lands were intentionally royal estates (Paulinyi, 1924; Ember, 1946; Zsámboki, 2005a; Zsámboki, 2005b). Two documents will be mentioned as examples for confirming the absence of the regalia in case of salt mining during that period: (1) the investigation performed to clarify the ownership of the salt mines in Ocna Sibiului at the order of Charles Robert in 1328 resulted in proving the longstanding proprietary rights of the provost in Sibiu (Paulinyi, 1924), (2) the land with all salt resources and salt mines in Solivar (now part of the town of Prešov in Slovakia) was a property of the Sóos family until 1570, the land being taken over by the treasury as a result of a long lasting litigation (Wenzel, 1880; Paulinyi, 1924; Szücs, 1990). During this period the salt mines in Dej, Cojocna, Sic and Turda were in the property of the kings (Paulinyi, 1924; Zsámboki, 2005b).

Even if the mining of salt was not a regalia at that time, Ember Gy. (1946) thinks that some related activities, such as salt trading, were retained as a royal right. In contrast to Ember's statement, Zsámboki (2005b) says that the customs duty of the salt in the $11^{\text {th }}$ century proves its free trading - the king did not subject his own product to additional costs. Paulinyi (1924) finds that the small number of royal salt depositories during the $13^{\text {th }}$ century supports the theory of free trading with salt products, but the placement of these offices in the border areas of the kingdom shows that the commerce with foreign countries was transacted by the royal trade office. 
Some of the sources (Iványi, 1911; Ember, 1946) link the occurrence of the regalia of salt to a law of 1492 (Art. 30), that clearly says that all the salt mines are kept under royal authority - the text of the law is to be found in the work of Izsó (2006). Before this act, in 1362, in his donation charter that includes the Catholic Church in Veszprém, Louis I of Hungary already mentioned the Royal Chamber System, responsible for the Transylvanian royal salt products. The Chamber had an overall control and supervision over all the activities of the salt mines and trading in accordance with the royal salt monopoly (Izsó, 2006).

A document issued by Matthias Corvinus in 1471 can be considered one of the first notes concerning the regulation of salt waters. Through this act, the king approved the usage of salt water wells for the wealthy citizens of Bistrița with respect to their long-lasting rights in this field (Izsó, 2006). This decision of the king seems to represent a privilege for the inhabitants of Bistrița which means that the usage of salt waters probably was under a general limitation.

It was already proven that during the $13^{\text {th }}$ century the production of salt was based on the land-ownership and trading was also permitted under a few restrictions. At the beginning of the $14^{\text {th }}$ century the case of Ocna Sibiului salt mines alludes to the rights induced by the still existing land-ownership, but documents from the second part of the same century testify the royal monopoly of both activities. The case of Solivar can be interpreted as an exception since the litigation process took a long time. The usage of salt waters was a privilege for some people or some settlements long before the year 1471. All the information presented before suggest that the regalia over all activities related to salt resources was introduced probably in the second part of the $14^{\text {th }}$ century.

The supervision of the salt resources performed by the Royal Chamber was functioning efficiently until the beginning of the $16^{\text {th }}$ century (Ember, 1946), while after this period the overall authority of the Hungarian Royal Chamber was also interrupted due the territorial partition caused by the Ottoman invasion.

\subsection{The unstable management of the salt resources during the Principality of Transylvania and the beginning of the Habsburg domination}

From the beginning of the era of the Principality of Transylvania, the administration of the salt resources located on the Transylvanian territory was separated from the Hungarian one until the Austro-Hungarian Compromise of 1867. Since they became a property of the Transylvanian prince, the salt mines were administrated by the state or were hired out for some periods of time. 
During the Principality the chamber-system responsible for the supervision of the salt mines and all salt resources did exist, but it was probably weakened (Wenzel, 1880; Wolf, 1993; Ember, 1946).

During these poorly organized times, we believe that a lighter degree of control was applied over the salt waters, even if the valid legislation in the mid $17^{\text {th }}$ century stated that the salt mines were in the possession of the Transylvanian Chamber. The opening of new mines was possible with the exclusive permission of the prince, but the nobility had the privilege to use for his own need the salt resources located on his property $(* * *, 1779)$. All along the existence of the Transylvanian Principality the exploitation and supervision of mineral resources was the most effective and successful during the reign of Prince Bethlen Gábor (Wenzel, 1880).

Indirect information about the situation of salt resources during this period is to be found in Orbán B. deputy's speech that was held at a parliamentary sitting in the mid $19^{\text {th }}$ century. During the Principality, the income induced by the domestic consumption of salt was small because large amounts were distributed free of charge among the nobility, the Szeklers, privileged churches and schools. The trade with salt was mostly carried out as export. The salt water from springs and wells was permitted to be used freely by the people belonging to the lower class (Szathmáry, 1886).

A great change was brought to this land with the installation of the Habsburg domination at the beginning of the $18^{\text {th }}$ century. During the ongoing organization of the new system, some of the sources that generated the incomes of the Transylvanian Treasury were subjected to a general hire out. The salt mines and all the tools conditioning the exploitation and transportation were in bad condition (because of the Turkish-Habsburg wars) and needed investment. Neither the Austrian Chamber nor the Transylvanian estates took over this sector (Trócsányi, 1988). Finally, with the entry of private investors, the exploitation and commerce with the Transylvanian salt started again, but it had difficulties because of personal interests. As a consequence of a negative report of the imperial messenger, the Austrian Imperial Court Chamber took the control over the whole salt industry and centralized it (Trócsányi, 1988). After another uncertain period (Rakoczi's War of Independence) the attention to salt regalia became much more emphasized. It was clearly declared that all the salt mines, salt water springs and wells were in the property of the Imperial Treasury (Fallenbüchl, 1979; Zsámboki, 2005c). The serious oversights, the suppression of foreign salt products by introducing new regulations, the high internal prices for salt led to a remarkable contribution of the incomes generated by salt-related activities to the general imperial revenue: $20 \%$ in $1760-1804,40 \%$ in 1828 , 35\% in 1838-1846 (Zsámboki, 2005c). 
Starting from the second part of the $18^{\text {th }}$ century, the situation of the salt water resources is described in various bibliographic sources related to natural sciences and ministerial decrees. There is a large literature dealing with this topic (mostly about the mines, but about the waters as well) as a result of the developments achieved in researching methods, more publishing opportunities and a great national interest for salt resources.

\subsection{Scientific papers, as sources of information regarding the regulation of usage of salt waters during the $18^{\text {th }}$ and the mid $19^{\text {th }}$ centuries}

Throughout the $18^{\text {th }}$ and $19^{\text {th }}$ centuries, until the middle of the $20^{\text {th }}$ century, the salt water resources were considered as a property of the Imperial or National Treasury. Their regulation and supervision became more and more rigorous. Johann Ehrenreich von Fichtel (1780) seems to be the first author giving a map and a very detailed scientific description about the Transylvanian salt as a rock (geology), the salt mining, salt waters and some regulations. Considering Fichtel's work (1780) we can have a general overview about the legislation and regulation of usage of the salt waters in Transylvania at the end of the $18^{\text {th }}$ century.

The salt (in any form of it, including salt waters) was one of the regalia goods meaning that nobody was allowed to use it without the special permission of the Emperor. Those persons who broke or limited the rules of the regalia (digging a salt pit or salt water well, using or selling the extracted product, stealing from the imperial mines, selling the officially purchased salt, importing salt from foreign countries), were to be punished. The whole salt industry was administrated and supervised by the Transylvanian Chamber that was subordinated to the Austrian Imperial Chamber. There were six salt offices in Transylvania marking the active salt mining places: Turda, Cojocna, Ocna Dej, Ocna Sibiului, Sic and Praid.

The springs and wells were guarded by a special staff called saltguards, hired by the Chamber to prevent the stealing of the salt resources. Strong measures were taken to fight against theft, such as filling in the springs and wells that were located in the vicinity of an arranged, well known, guarded source. If a new spring was discovered, first of all it had to be announced to the Chamber. If that new spring was located on a plot of land of a settlement (not belonging to the imperial properties), and it had a natural origin, the community had the right to transform it into a well. This well had to be arranged with a built house above it which had to have two locks on it. One of the keys was held by the mayor of the settlement, while the other one by the salt-guard. Two days a 
week the community could take a predetermined amount of salt water from the well under the supervision of the mayor and the salt-guard. Fighting against theft was the community's duty as well, since they could lose the right of using the salt water if a fraud had happened. Finally the rule concerning the frequency of usage was extended to the older wells as well (Fichtel, 1780). Probably this rule regarding the management of the salt waters existed long before Fichtel's era, but he revealed that in practice guarding these resources was not taken so seriously.

The fact that the usage of salt waters was permitted under strict rules is confirmed by other bibliographic sources as well in the first part of the $19^{\text {th }}$ century (Benigni von Mildenberg, 1837; Bielz, 1857; Hunfalvy, 1864; Mosel, 1865a). Natural occurrences of salt water continued to be guarded. Citizens of such settlements, where salt water sources were present, were allowed to take water under supervision twice a week for their own needs without giving it away or selling it. Salt guarding and observing the law were taken more and more seriously. We believe that the aim of restricting the usage of natural sources was to force people to purchase the salt products offered by the state. In order to illustrate how attached the Chamber was to generate income we need to mention that thousands of tons of salt debris that accumulated during the mining activities were thrown into the rivers yearly rather than selling it at a lower price (Mosel, 1865a; Schmidt and Liszkay, 1871).

Starting with the second part of the $19^{\text {th }}$ century the scientific literature does not deal with the issue of regulation.

\subsection{Official documents, as sources of information regarding the regulation of usage of salt waters during the $19^{\text {th }}$ century}

Topics from two parliamentary sittings (7th and 8th of May, 1844, CXLII and CXLIII parliamentary sittings) and a correspondence between Deák F., Ministry of Finance, and Kossuth L., Ministry of Justice in mid 19th century point out how problematic the salt question was at that time. In this decade, for a small period (during the Hungarian Revolution of 1848-49) Transylvania was attached to Hungary, so decisions made in the salt issue refer to the Transylvanian sites as well.

Deputies from Borsod and Maramureș counties, in their speech, discussed the question of salt resources. They believed the phrasing that the salt belongs to the crown would mean that it is a common property of the whole country and it does not belong exclusively to the emperor. The other interpretation of the law which says that 'salt mines are owned by the emperor' reveals that actually salt water springs and wells are not part of the mines and hence the free usage of them should be permitted ( $\left.{ }^{* * *}, 1844 \mathrm{a} ;{ }^{* * *}, 1844 \mathrm{~b}\right)$. 
The correspondence between the two ministers in 1848 (Molnár, 1998) explains that the problem was understandable since the legal background did not specify exactly the status of salt waters. Based on the law that states that everybody must have - sell, buy or consume - only inland (Hungarian) salt does not follow that the salt springs usage is to be prohibited. It also reveals that the measures that were taken by the Treasury/Chamber to hinder the usage of salt waters were not actually legally acknowledged by the Hungarian state. The legally accepted action for the Treasury to make would have been the prohibition of preparation of solid salt out of salt water or the prohibition of selling the salt water. In this way people have the right to take salt water for their own needs and for their livestock. Finally the Transylvanian Parliamentary Act, with the number 1848/XI, enabled the free usage of salt water wells without any restriction (Márkus, 1896a).

After the Hungarian Revolution of 1848-49, the Austrian party acted very strictly in all items affecting the Hungarian issues. This was true to the handling of the salt resources as well. During a later parliamentary sitting, in 1868, deputy Gál J. explained in his speech that the low consumption of salt in Transylvania at that time could not be attributed to the usage of salt waters, because during the Austrian absolutist government generally two-thirds of the salt water wells and springs were filled in (Greguss, 1868). Surveillance of the salt resources continued all along the $19^{\text {th }}$ century. The Ordinance 203/1852 (***, 1852) emitted by the military and civil governor (placed in Transylvania) reveals that the places with salt rock and brines were guarded by two types of personnel. The ones guarding the solid salt resources were hired by the Ministry of Finance and had some privileges. The personnel guarding the salt waters were hired on local scale.

A new and long-lasting mining law was proclaimed by the emperor on the 23rd of May 1854. This Austrian General Mining Law, enforced on the whole territory of the Empire, did not discuss the salt issue. The statement, found in Chapter I, Paragraph 4, reveals that the salt resources were to be regulated by special laws because they made the subject of state monopoly $(* * *, 1854)$. The salt issue was put under the supervision of the Ministry of Finance (Balkay and Szeőke, 1901). In the forthcoming decades general acts $(1868 / \mathrm{XI}, 1875 / \mathrm{L}$, $1897 /$ I) were dealing only with defining the prices of salt rock and regulating the trading activities (Pfeifer, 1868; Márkus, 1896c; Márkus, 1898).

Balkay and Szeőke (1901) gathered all the regulations (ordinances and supplements) regarding the salt issue that came out in the second part of the $19^{\text {th }}$ century. This legislation was applied to the Transylvanian sites as well, since the territory was attached to Hungary again (Márkus, 1896b). According to the work of Balkay and Szeőke (1901), the salt issue continued to be an important 
factor during the entire $19^{\text {th }}$ century and the regulations described in the $18^{\text {th }}$ century continued to be maintained as well. Salt was considered as a subject of national excise. Salt (of any kind or in any form of it) found over or under the surface was the property of the state. The state had the exclusive right over the salt production/exploitation through mining activities or production from salt water. Anyone who found a salt site or salt water or a mixture of other ingredients with salt had the obligation to report it to the nearest financial office. In order to maintain the authority over all salt resources, the Treasury/Chamber had the right to fill in those salt springs that could not be useful for state purposes. In Transylvania and Maramureș, the practice of usage was allowed with the permission of the Ministry of Finance and under restrictions only for those people who had salt springs or wells near their settlements. It was forbidden to dig the spring into a well or to produce solid salt out of salt water without the permission of the financial authority. Based on the Ordinance no. 4231/878 issued by the Ministry of Finance, the import or transit of any foreign salt product, including the salt waters, was also generally forbidden. It was only allowed in exceptional cases with a special license from the Ministry of Finance $(* * *, 1879)$.

In the first decades of the $20^{\text {th }}$ century, focus shifted on the potassium salts, due to the discovery of their high importance in agriculture (Láng, 1910). The beginnings of this trend were already noticeable in the second part of the $19^{\text {th }}$ century, when regarding to a new, Hungarian mining law proposal (that was not accepted by the Emperor in the end), it was recommended that the common term "salt" should be specified and used as "NaCl salt" when referring to this compound $(* *, 1871)$. Finally, through the Parliamentary Act VII/1911 potassium salts were attached to the state monopoly subjects beside the $\mathrm{NaCl}$ salt (Alliquander et al., 1931). This suggests that, on the basis of the monopoly, all the strict ordinances that were applied before concerning the salt resources, including the salt waters, were true in the first decades of the $20^{\text {th }}$ century as well.

\subsection{Changes in the appreciation of the salt resources during the $20^{\text {th }}$ century}

The interwar period brought big changes throughout the Transylvanian territory, since it became part of Romania. The subject matter of raw materials and mining were put under the supervision and enforcement of the Romanian Ministry of Industry and Commerce, while the direct coordination was made by the Mining Authority (***, 1924). The Romanian Constitution of 1923 (Art. 19.), published in the Official Journal of Romania (Monitorul Oficial al României, no. $282 / 29^{\text {th }}$ of March, 1923), stated that all minerals and all subsurface resources are 
in the property of the state. This statement was corroborated with the Decree on the Mining Law no. 2.294 on the $3^{\text {rd }}$ of July 1924, published in the Official Journal of Romania (Monitorul Oficial al României, no. 143/4th of July 1924). This document contains the regulations concerning salt resources including the salt waters as well. Art. 213 of the Mining Law declares that exploitation or extraction of salt through groundwork or dissolution and pumping or from salt springs and any other natural salt solution (salt groundwater, lakes, seawater) is the subject of state monopoly. This right is exercised by the Direction of State Monopolies. Art. 214 declares that salt trading is the exclusive right of the state and is transacted by the Ministry of Industry and Commerce. This right can be transferred partially to a private company or investor in such a way that a joint organization is established. Art. 215 says that any explorer or mining operator who encounters salt deposits or high concentration salt water has the obligation to notify the regional mining authority within three days. Art. 217 explains that the usage of salt water for bathing purposes in health resorts is allowed under the general regulation of mineral and therapeutic waters, but it is forbidden to extract crystalline salt from these waters.

This Mining Law, that suffered minor changes in 1929 and 1937, was in force until the Second World War (Baron and Dobre-Baron, 2001). With the nationalization law of $1948(* * *, 1948)$ all the subsurface resources were declared again to be the property of the state (Art. 1) and it was in force until the end of 1980s / beginning of 1990s (end of communism in Romania).

István L. (1978) described most of the activities related to salt waters in Corund (Hungarian Korond, Harghita County) area in the first part of the $20^{\text {th }}$ century. The habits that evolved among the people were the consequence of official regulations and were probably true to the whole Transylvanian area.

People were allowed to take salt water from the well once a week. The amount of water that could be taken was different for each family and was determined based on the number of family members and livestock at the beginning of each year. Based on these yearly calculations a so called salt card or salt ticket was issued by the salt-adjudicator that had to be paid at the communal cash desk. Half of this payment was spent on maintaining the salt well. The position of salt-adjudicator existed until the end of the 1950s. The disappearance of this function seems to mark the beginnings of a lower appreciation of the salt itself. In the 1970s no permission was needed anymore to take and use salt water.

Guarding the salt water places by salt-guards was active until the First World War when the issue of salt resources was subordinated to the Hungarian Ministry of Finance. After the First World War, no record was found to support the existence of this rigorous supervision of the resources. During the interwar 
period the salt materials were a subject of Romanian State Monopoly, with penalties if breaking the rules $\left({ }^{* *}, 1924\right)$, but probably without guarding these places. During the Second World War, when a part of Transylvania was attached to Hungary, the old Hungarian restrictions came back, but because of wartime conditions, controlling and supervision of the sites was not taken so seriously $(* * *, 1941)$.

We suppose that a change was brought to the issue of salt with the nationalization law in 1948 in Romania, since this legislation has eliminated its privileged status and treated it in a similar manner to the other resources.

\section{A REVIEW OF THE LITERATURE ON TRANSYLVANIAN SALT WATER RESOURCES}

Of all the scientific works dealing with the subject of salt water resources, four could be mentioned as being the most comprehensive and the most detailed. This literature covers the period from the end of the $18^{\text {th }}$ century until the end of the $19^{\text {th }}$ century and provides valuable information about the salt water resources from the era when salt was most appreciated. The focus in Fichtel's work (1780) is put mostly on rock salt, but he also publishes a list and a map with the places where salt waters appear on surface. At the beginning of the $19^{\text {th }}$ century many authors use the data from Fichtel, so the first, very detailed list about the salt water places with the number of wells and springs discussed separately is published by Czekelius (1854). The following list with updates concerning the number of sources is related to Bernáth J. (1880) who published the results of a former survey (1873) that was made under official control. Compared to the previous articles, the value of Fischer's work (1887) is that he made chemical analyzes on the water samples that were sent to him, beside the presentation of the springs and wells for each settlement.

A new evaluation about the Transylvanian salt waters was initiated again by the state (Ministry of Finance) with the purpose of identifying potassium salts dissolved in water - the state was interested in potassium salts (deposits) since the discovery of their positive effects in agriculture as fertilizers. This survey was mostly made by Kalecsinszky S., but starting from 1907 Budai E. was responsible for gathering the salt water samples on the western side of the Transylvanian Basin (Kalecsinszky, 1902; 1903; 1905; 1909). Kalecsinszky (1909) reported that in order to gather the water samples for detailed analyses in the laboratory, they dig out many wells and springs that were filled in before. Based on our current knowledge the results of this survey regarding the $\mathrm{NaCl}$ salt waters were not published. 
A new, survey-like investigation of the brackish waters and brines in Transylvania was not made since the beginning of the $20^{\text {th }}$ century. Sturza M. (1930) in his work concerns the issue of the Transylvanian brines, but he mentions just a few examples from this area. In recent works the trend in research ideas is to analyze in detail from hydro-geo-chemical point of view some water samples from selected sources (Baciu et al., 2001; Cuna et al., 2001; Berdea et al., 2005; Kis, 2013; Braşovan et al., 2015). This kind of approach has its strengths, but a general, detailed, survey-like, systematic analysis is still missing.

\section{MATERIALS AND METHODS TO THE CASE STUDY}

In order to make a comparison between the number of salt sources described in the past and the present situation, we carried out a survey in 2016 by visiting the old salt water locations and looking for new sites in the area South of Cluj-Napoca. The locations for observation were selected based on the geology of the plot and lack of vegetation.

Shallow and deeper groundwater samples were analyzed by measuring the electric conductivity values and sporadically the sulphate concentration. The measurements were carried out using a Thermo Orion Star portable multiparameter meter and a Hanna Sulphate portable photometer. When processing data for map display, the inverse distance power interpolation method was used with high value for power.

\section{CASE STUDY: SPRINGS AND WELLS IN THE AREA SOUTH OF CLUJ-NAPOCA CITY}

In 1780 Fichtel mentioned about 120 places in Transylvania where salt waters can be found with more than 300 sources. Czekelius (1854) talked about 192 salt wells and 593 salt springs, while Mosel (1865b) mentioned 216 salt wells and 622 salt springs. Published by Bernáth J. in 1880, the list of salt water resources made in 1873 refered to a number of 235 wells and 415 springs. Fischer (1887) registered 269 locations in Transylvania where salt waters were to be found at the surface. There are differences between the lists of these authors regarding not just the number, but also the locations of the sources that can be explained by the disappearance of some wells/springs or the emergence or discovery of new sources.

In the narrow area delimited by Cluj-Napoca and Turda, Fichtel (1780) mentioned eight places where salt waters were to be found and the other authors mentioned seventeen. It is possible that mistakes were made when 
identifying these locations. For example only Czekelius (1854) mentioned a salt water spring at Copăceni. This village is missing from all the other works, even if Fischer (1887) marks also those sources that have disappeared in most of the cases. Another ambiguous case is represented by the well in Pata area that could be probably the same with the well in Gheorgheni area, even if Fischer (1887) tried to eliminate these kinds of mistakes as well.

Table 1. Evolution of the number of salt water resources

\begin{tabular}{|c|c|c|c|c|c|c|c|c|}
\hline & \multicolumn{2}{|c|}{ Czekelius, 1854 } & \multicolumn{2}{|c|}{ Bernath, 1880 } & \multicolumn{2}{|c|}{ Fischer, 1887 } & \multicolumn{2}{c|}{ Present day } \\
\hline Settlements & well & spring & well & spring & well & spring & well & spring \\
\hline Cluj-Napoca & 0 & 3 & 0 & 3 & 0 & 4 & 0 & 2 (Sopor) \\
\hline Someșeni & 1 & 23 & 1 & 0 & 1 & 0 & 0 & 1 (+more) \\
\hline Dezmir & 1 & 4 & 1 & 4 & 1 & 3 & 0 & 1 \\
\hline Apahida & 1 & 6 & 1 & 1 & 1 & 0 & 0 & 0 \\
\hline Cara & 1 & 5 & 1 & 6 & 1 & 0 & 0 & 0 \\
\hline Cojocna & 0 & 20 & 1 & 10 & 1 & 5 & 1 & 4 \\
\hline Pata & 0 & 0 & 1 & 4 & 1 & 0 & 0 & 2 \\
\hline Gheorgheni & 1 & 0 & 1 & 0 & 1 & 0 & $\begin{array}{c}\text { not } \\
\text { visited }\end{array}$ & not visited \\
\hline Feleacu & 0 & 1 & 0 & 0 & 1 & 0 & 0 & 0 \\
\hline Aiton & 1 & 1 & 1 & 0 & 1 & 0 & not & not visited \\
\hline Rediu & 1 & 0 & 1 & 0 & 1 & 0 & 0 & 0 \\
\hline Ceanu Mic & 1 & 0 & 1 & 0 & 1 & 0 & 0 & 2 \\
\hline Micesti & 1 & 2 & 1 & 5 & 1 & 0 & 1 & 0 \\
\hline Deleni & 1 & 0 & 1 & 0 & 1 & 0 & 1 & 0 \\
\hline Petreștii de Jos & - & - & 1 & 0 & 1 & 0 & 0 & 1 \\
\hline Copăceni & 0 & 1 & - & - & - & - & not & not visited \\
\hline Turda & 0 & 0 & 1 & 1 & 1 & 3 & not & visited \\
\hline
\end{tabular}

A settlement generally had one salt-water well during the $19^{\text {th }}$ century (table 1). The long term survival of the wells supports the habit of visiting (under restrictions) and maintaining these places. Unlike the wells, the number of springs shows a general decrease until the end of the $19^{\text {th }}$ century (table 1). The 
literature of this topic says that people were allowed to use one well/village under supervision. Filling in the additional salt water sources was practiced mostly during the Austrian absolutist government (first part of the $19^{\text {th }}$ century), but the law that allowed this act was in force until the first part of the $20^{\text {th }}$ century. The wells were very well known, arranged places, and usually fed by shallow groundwater. Springs are generally more sensitive to the environmental changes and have lower discharge. The sporadic distribution of springs probably caused some difficulties when finding these items. All these could be the reason why the number of springs decreased; destroying them must have gone more slowly. The sources in Cojocna area were included in the table in order to illustrate the disappearance of springs over time.

We do not know how the number of these sources changed gradually during the $20^{\text {th }}$ century. The present day situation shows a small number of salt water sources (table 1). Out of thirteen visited places that each had one well in 1887, only three have salt water as well in present day: Cojocna, Micești and Deleni. Active springs can be found in Cluj-Napoca (Sopor area), Someșeni (now part of Cluj-Napoca), Pata and Cojocna. The former springs in Dezmir are active as well and currently are part of the administrative area of Cluj-Napoca - the spring(s) that feed the salt pond at Pata-Rât. The sources that can be found in Ceanu Mic and Petreștii de Jos are just leakages and are located on the site where the former active sources were. None of the springs are protected or maintained. We believe that the drastic change in the number of salt water resources during the $20^{\text {th }}$ century (probably the second part of the century) can be attributed to the disinterest, negligence and indifference of the people since the salt products are easily accessible on the market.

Settlements where salt water wells and springs were and are still present are marked on a geological background map (fig. 1) since the origin of the salinity is related to the Badenian salt deposits. There are fewer cases (Dezmir, Pata, Deleni) when these sites are in direct connection with the Badenian sedimentary, salt-bearing strata. In most of the cases the surface layer where the brines appear are Sarmatian sedimentary deposits or Holocene alluvialdelluvial deposits. The salt sites at Pata and Someșeni are directly linked to anticlines (fig. 1), but the presence of brines at the other locations may suggest that either the covering strata (Sarmatian or Holocene deposits) could be thin or the movement of water is ascending from deeper layers.

If the pathway of ascending water is interrupted close to the surface, the "water-course" can continue to circulate through other shallow subsurface routes to emerge as a spring at other location. From this point of view, using the old descriptions, we investigated the closer surroundings of the former springs and those areas where the Badenian, salt-bearing strata are at the surface. Figure 2 
presents the electric conductivity of shallow groundwater and the known brines from 35 sample points on the area located South of Cluj-Napoca City, a transitory zone between the Miocene sediments and the Paleocene-Eocene sediments of the Transylvanian (western) Basin.

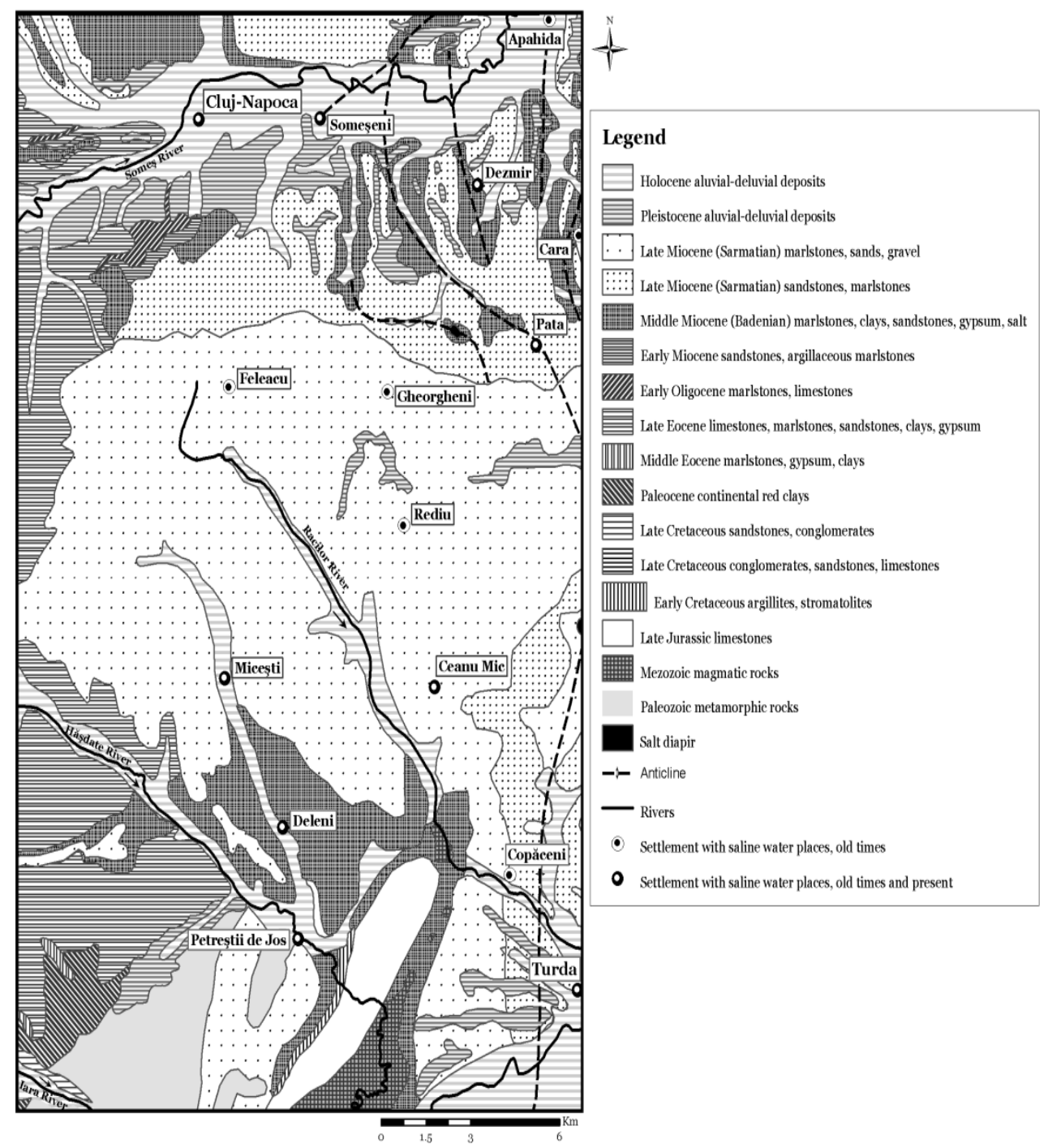

Fig. 1. Settlements with salt water resources represented on a geological background map (source for geology: Răileanu and Saulea, 1967; Giușcă and Bleahu, 1967) 


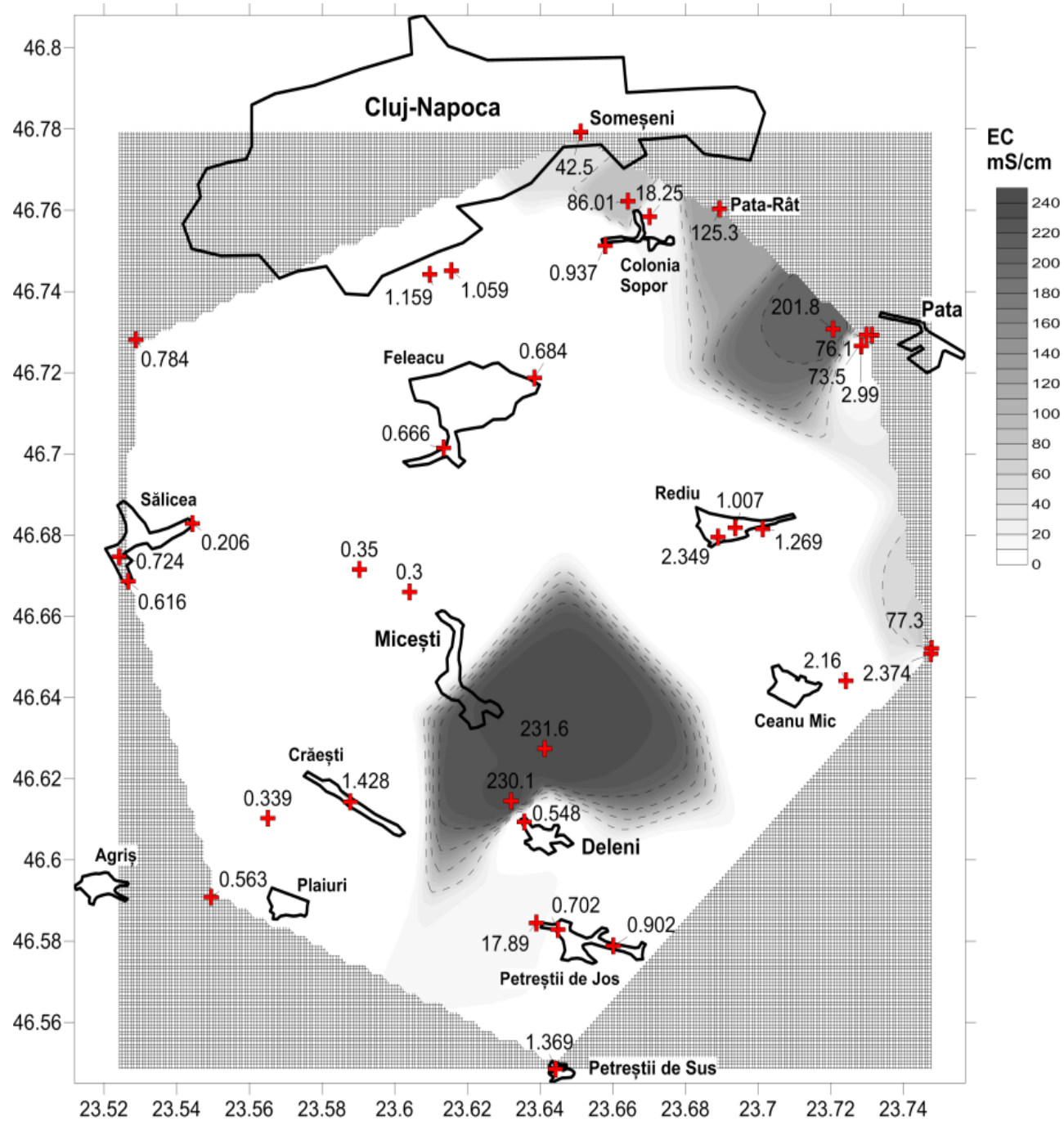

Fig. 2. Electrical conductivity values of samples from the area South of Cluj-Napoca

The brines located at Someșeni, Sopor, Pata-Rât, Pata and to the west of Ceanu Mic (positioned along a continuous line that heads to Turda) could be associated with the most western anticlines that bring the salt close to the surface. These could be pointy, narrow salt intrusions, since the mineralization of groundwater in the vicinity of the brines is already low in many cases in comparison to the high concentration of the brines. 
The Micești-Deleni area seems to be the most western salt site between Cluj-Napoca and Turda. These wells have the highest mineralized water $(\approx 230$ $\mathrm{ms} / \mathrm{cm}$ ) with high sulphate concentration $(4.6 \mathrm{~g} / \mathrm{l}$ in the sample from Micești). These data suggest that this separate salt site may be fed by deeper, ascending water. No other salt sites were identified across the rest of the area.

\section{6. (INSTEAD OF) CONCLUSIONS}

Salt waters are surface or subsurface natural resources. The appreciation of these sources has changed during the centuries from highly valuable but freely used status to the degree of highly appreciated with usage restrictions. Nowadays it seems to have a generally lower degree of recognition. At a closer look, it can be noticed that the salt is still important to the country's economy, since it is used on large scales by the industry while salt waters are utilized in balneotherapy, but there is no such a high degree of enthusiasm for it, as it was during the $18^{\text {th }}$ and $19^{\text {th }}$ centuries. This transformation could be explained by multiple changes that happened in other fields, like the development of the mining technology, the abundant supply of the market with these products or the consumers' behaviour. We believe that answering this question belongs to other scientific fields.

Among traditionally organized communities, these waters are still in use and some settlements still have their own salt water well. Springs are not used or protected. The usage of water is free of charge; the restrictions, if any, serve the protection of the sources (for example at Corund and Lueta in the eastern part of the Transylvanian Basin). The brine wells at Cojocna, Deleni and Micești are under usage and can be visited any time, but they are treated with less care.

The number of the salt sources is not as high as it was in past centuries. It would be recommended to pay more attention to these sites not just in order to protect them as a resource but also to have a better understanding of their hydrogeological characteristics.

\section{ACKNOLEDGEMENTS}

The authors would like to thank István Gábos, Ibolya Gábor and George Şchiopu for their help during the field observations and measurements. 


\section{REFERENCES}

1. Alliquander, Ö., Bán, I., Tassonyi, E. (1931), Magyar Bányajog, Athenaeum Irodalmi és Nyomdai RT., Budapest.

2. Baciu, C., Cosma, C., Berdea, P. (2001), An approach to the dynamics of mineral waters from Someseni Spa (Romania), XXXI. Congress of the IAH International Association of Hydrogeologists "New Approaches to Characterising Groundwater Flow", Munich, Germany.

3. Balkay, B., Szeőke, I. (1901), Magyar bánya-jog. A teljes joganyag hivatalos adatok alapján, Apolló Irodalmi és Nyomdai Részvénytársaság, Budapest.

4. Baron, M., Dobre-Baron, O. (2001), Caracteristici ale mineritului românesc din perioada interbelică, Annales Universitatis Apulensis, Series Historica, Nr. 45/2000-2001, Universitatea "1 Decembrie 1918" din Alba Iulia.

5. Benigni von Mildenberg, J. H. (1837), Handbuch der Statistik und Geographie des Großfürstenthums Siebenbürgen, III. heft, Geographie, Hermannstadt.

6. Berdea, P., Cuna, S. M., Balas, G., Hauer, E. (2005), Origin of mineral waters from Someseni, Transylvanian Basin, Romania, Geologycal Quarterly, 49 (2).

7. Bernáth, J. (1880), Erdély konyhasó-vizei, Földtani közlöny, Vol. 10., Number 67, pp. 200-217, Budapest.

8. Beudant, F. S. (1822), Voyage minéralogique et géologique, en Hongrie, Paris.

9. Bielz, E. A. (1857), Handbuch der Landeskunde Siebenbürgens, Hermannstadt.

10. Brașovan, A., Câmpean, R. F., Olah, N. K., Morgovan, C., Popescu, C., Atyim, P. (2015), Physico-chemical characterization of spring and salt lakes from Someșeni and Tureni (Cluj County), Studia UBB Chemia, LX, 1.

11.Brown, E. (1670), Some Directions and Inquiries with their answers concerning the mines, minerals, baths of Hungary, Transylvania, Austria and other countries neighbouring them, Philosophical Transactions, Vol 5., Number 58, pp. 1189-1198.

12.Cuna, S., Berdea, P., Baciu, C. (2001), Isotopic investigations on the mineral waters from Someseni - Cluj, Romania, Studia UBB Physica, Special Issue.

13.Czekelius, D. (1854), Die Verbreitung der Salzquellen und des Steinsalzes in Siebenbürgen, Verhandlungen und Mittheilungen des siebenbürgischen Vereins für Naturwissenschaften zu Hermannstadt, Jahrgang V., No. 3.

14.Ember, Gy. (1946), Az újkori magyar közigazgatás története Mohácstól a török kiüzéséig, A Magyar Országos Levéltár Kiadványai, III. Hatóság- és Hivataltörténet, Irodalmi, Művészeti és Tudományos Intézet, Budapest.

15. Fallenbüchl, Z. (1979), A sóügy hivatalnoksága Magyarországon a XVIII. században, Levéltári Közlemények, Vol. 50., Number 2., Akadémiai Kiadó, Budapest.

16.Fichtel, J. E. (1780), Geschichte des Steinsalzes und der Steinsalzgruben im Grossfürstenthum Siebenbürgen, Beytrag zur Mineralgeschichte von Siebenbürgen, Zweiter Theil, Nürnberg. 
17.Fisher, S. (1887), Magyarország konyhasós vizei, Földtani közlöny, Vol. 17., Number 9-11, pp. 377-448, Budapest.

18.Giușcă, D., Bleahu, M. (1967), Harta geologică a Republicii Socialiste România, Nr. 18, Turda, 1:200.000, Institutul Geologic, București.

19.Greguss, Á. ed. (1868), CCXLIII. Országos Ülés, 1868. junius 19., Országgyúlés Képviselőházának Naplója, VIII. Kötet, Országgyűlés Nyomtatványai, Athenaeum Nyomda, Pest.

20.Henshaw, T., Hill, A. (1666), Inquiries for Hungary and Transylvania, Philosophical Transactions, Vol. 2., Number 25, pp. 467-472.

21.Hunfalvy, J. (1864), A magyar birodalom természeti viszonyainak leírása, II Kötet, IV és V füzet, Emich Gusztáv magyar akad. Nyomdásznál, Pest.

22.István, L. (1978), A korondi sósvíz és használata, Népismereti dolgozatok, Kriterion Könyvkiadó, Bukarest.

23.Iványi, B. (1911), Két középkori sóbánya statutum, Századok, Vol. XLV., Budapest.

24.Izsó, I. (2006), Szemelvények a középkori montanisztika magyarországi történetének írott forrásaiból (1000-1526), Érc- és Ásványbányászati Múzeum Alapítvány, Rudabánya.

25.Kalecsinszky, S. (1902), Közlemények a Magyar Királyi Földtani Intézet chemiai laboratóriumából: Az Erdélyrészi sóterületek tanulmányozása, A Magyar Királyi Földtani Intézet Évi Jelentése 1900-ról, Franklin-Társulat Könyvnyomdája, Budapest.

26. Kalecsinszky, S. (1903), Közlemények a Magyar Királyi Földtani Intézet chemiai laboratóriumából: Az Erdélyrészi sóterületek tanulmányozása, A Magyar Királyi Földtani Intézet Évi Jelentése 1901-ről, Franklin-Társulat Könyvnyomdája, Budapest.

27.Kalecsinszky, S. (1905), Közlemények a Magyar Királyi Földtani Intézet chemiai laboratóriumából, A Magyar Királyi Földtani Intézet Évi Jelentése 1904-ről, Franklin-Társulat Könyvnyomdája, Budapest.

28. Kalecsinszky, S. (1909), Közlemények a Magyar Királyi Földtani Intézet chemiai laboratóriumából, A Magyar Királyi Földtani Intézet Évi Jelentése 1907-ről, Franklin-Társulat Könyvnyomdája, Budapest.

29. Kis, B. M. (2013), Hydrogeochemistry of mineral waters from the Eastern Carpathians Transylvanian Basin boundary, PhD thesis, Babeș-Bolyai University, Faculty of Environmental Science and Engineering, Cluj-Napoca.

30.Láng, M. (1910), Az uj állami monopoliumok, Közgazdasági Szemle, Vol. XXXIV, Nr. 44, Pesti Könyvnyomda-Részvény-Társaság, Budapest.

31.Márkus, D. ed. (1896a), XI. Törvény-czikkely. Sóárról és sóskutakról. 1848. évi erdélyi országgyúlési törvényczikkek. Magyar Törvénytár 1836-1868. évi Törvényczikkek, Corpus Juris Hungarici. Magyar Törvénytár 1000-1895. Milleniumi Emlékkiadás, Franklin Társulat, Magyar Irod. Intézet és Könyvnyomda, Budapest. 
32.Márkus, D. ed. (1896b), XLIII Törvény-czikk Magyarország és Erdély egyesitésének részletes szabályozásáról, 1868 évi törvényczikkek, Magyar Törvénytár 1836-1868. évi Törvényczikkek, Corpus Juris Hungarici. Magyar Törvénytár 1000-1895. Milleniumi Emlékkiadás, Franklin Társulat, Magyar Irod. Intézet és Könyvnyomda, Budapest.

33. Márkus, D. ed. (1896c), L. Törvény-czikk a sójövedékrôl szóló 1868. évi XI. t. cz. és a sójövedéki szabályok némely intézkedéseinek módositásáról. 1875. Évi törvényczikkek. Magyar Törvénytár 1875-1876. évi Törvényczikkek, Corpus Juris Hungarici. Magyar Törvénytár. 1000-1895 Milleniumi Emlékkiadás, Franklin Társulat, Magyar Irod. Intézet és Könyvnyomda, Budapest.

34.Márkus, D. ed. (1898), I. Törvény-czikk a mérsékelt árú marhasóról. 1897. Évi törvényczikkek. Magyar Törvénytár 1897. évi Törvényczikkek, Corpus Juris Hungarici. Magyar Törvénytár. Milleniumi Emlékkiadás, Franklin Társulat, Magyar Irod. Intézet és Könyvnyomda, Budapest.

35. Molnár, A. (1998), Deák Ferenc igazságügyi miniszteri irataiból - 29. Pest, 1848. június 10. Deák Ferenc igazságügyi miniszter átirata Kossuth Lajos pénzügyminiszterhez, ed. Molnár A.: A Batthyány-kormány igazságügyi minisztere, Zala Megyei Levéltár, Zalaegerszeg.

36. Mosel, A (1865a), A só mindenüttségéről és közgazdászati jelentôségéról: Erdély só bőségérôl és sóászatáról, ed. Szabó J.: A Magyar Orvosok és Természetvizsgálók 1864 Augustus 24-től September 2-ig Maros-Vásárhelytt tartott X. Nagygyülésének történeti vázlata és munkálatai, Ásvány-, Föld- és Vegytani Értekezések, Emich Gusztáv Magyar Akadémiai Nyomda, Pest.

37.Mosel, A (1865b), Földismei és államrajzi adatok az erdélyi cs. kir. sóbányászatról. 5 átnézetben., ed. Szabó József: A Magyar Orvosok és Természetvizsgálók 1864 Augustus 24-től September 2-ig Maros-Vásárhelytt tartott X. Nagygyülésének történeti vázlata és munkálatai, Ásvány-, Föld- és Vegytani Értekezések, Emich Gusztáv Magyar Akadémiai Nyomda, Pest.

38.Paulinyi, 0. (1924), A soregálé kialakulása Magyarországon, Századok, Vol. LVIII., Number 1-6., 627-647 p., Budapest.

39.Pfeifer, F. ed. (1868), 1868-ik évi XI. Törvény-czikk a sójövedék iránt. 1868. Évi törvényczikkek. Magyarországi Törvények és Rendeletek Tára, II. Folyam, 1868. Január-junius, Emich Gusztáv m. akad. Nyomdásznál, Pest.

40.Răileanu, Gr., Saulea, E. (1967), Harta geologică a Republicii Socialiste România, Nr. 10, Cluj, 1:200.000, Institutul Geologic, București.

41.Schmidt, A., Liszkay, G. (1871), A kôsó bányák Erdélyben, Bányászati és Kohászati Lapok, Vol. 5, Nr. 24.

42.Sturza, M. (1930), Die Kochsalzwässer Romäniens - Balneologisch-balneotherapeutische studie, Wien.

43.Szathmáry, K. ed. (1886), Az 1884-87. évi Országgyúlés Képviselőházának Naplója, VIII. kötet - 167. Országos Ülés, 1886. évi január hó 23-án, Országggyűlés Nyomtatványai, Pesti Könyvnyomda Részvény-Társaság, Budapest. 
44.Szűcs, J. (1990), A Szepesi Kamarai Levéltár 1567-1813, A Magyar Országos Levéltár Kiadványai, I Levéltári Leltárak, 7. Kincstári Levéltárak, Akadémiai Kiadó, Budapest.

45.Trócsányi, Zs. (1988), Habsburg-politika és Habsburg-kormányzat Erdélyben 1690-1740, A Magyar Országos Levéltár Kiadványai, III. Hatóság- és Hivataltörténet 8., Akadémiai Kiadó, Budapest.

46.Wenzel, G. (1880), Magyarország bányászatának kritikai története, A Magyar Tudományos Akadémia Könyvkiadó Hivatala, Budapest.

47.Wolf, R. (1993), Torda város tanácsi jegyzőkönyve 1603-1678, Erdélyi Történelmi Adatok VI.1., Erdélyi Múzeum Egyesület, Kolozsvár.

48.Zsámboki, L. (2005a), Bányászat az Árpádok korában (896-1301), Selmeci ezüst, körmöci arany - Válogatott tanulmányok a szerző születésének 70. évfordulója tiszteletére, Érc- és Ásványbányászati Múzeum, Rudabánya - Miskolc.

49.Zsámboki, L. (2005b), Sóbányászat, sókereskedelem és sóadományok, Selmeci ezüst, körmöci arany - Válogatott tanulmányok a szerző születésének 70. évfordulója tiszteletére, Érc- és Ásványbányászati Múzeum, Rudabánya - Miskolc.

50.Zsámboki, L. (2005c), Kösótermelés és kereskedelem a 18. században, Selmeci ezüst, körmöci arany - Válogatott tanulmányok a szerző születésének 70. évfordulója tiszteletére, Érc- és Ásványbányászati Múzeum, Rudabánya - Miskolc.

51.*** (1666), A preface to the third year of these tracts, Philosophical Transactions, Vol. 2., Number 23, pp. 414-415.

52.***, (1779) Erdély országának három könyvekre osztatott törvényes könyve, Református Kollégium Nyomdája, Kolozsvár.

53.***, (1844a), CXLII. Országos Ülés a tek. karoknál és rendeknél, Majus 7-én, 1844, Magyarországi Közgyúlésnek Naplója a tekintetes karoknál és rendeknél, IV. kötet Pozsonyban, Az Országgyúlési Irományok Kiadóhivatala, Landerer és Heckenast Nyomda, Pest.

54.***, (1844b), CXLIII. Országos Ülés a tek karoknál és rendeknél, Majus 8-án, 1844, Magyarországi Közgyülésnek Naplója a tekintetes karoknál és rendeknél, IV. kötet Pozsonyban, Az Országgyúlési Irományok Kiadóhivatala, Landerer és Heckenast Nyomda, Pest.

55.***, (1852), 203. szám. Rendelete a cs. k. katonai és polgári kormányzónak 1852diki october 13-ról, a sónyilámok öreinek közmunkatételtőli mentesitése tárgyában, Erdély koronaországot illető országos törvény- és kormánylap, Hermannstadt.

56.***, (1854), 173. számú 1854-diki május 23-kán kelt császári nyiltparancs, mellyel a birodalom egész területére egy általános bányatörvény bocsáttatik ki, Magyarországot illető Országos Kormánylap, V. Évfolyam, II. Kötet, XI-XXVII. Darab, Császári Királyi Egyetemi Nyomda, Pest.

57.***, (1871), Bányatörvény-javaslat, Bányászati és Kohászati Lapok, Vol. IV., Nr. 5 , Selmecz.

58.***, (1941), Csendőr Lexikon - newspaper section about the salt water springs, Csendőrségi Lapok, Vol. XXXI., Nr. 9, Budapest. 
59.***, (1879), A m. kir. Pénzügyministernek 4231/878. sz. körrendelete, a dohány és só be- és átvitelére nézve megállapitott határozmányok tárgyában, Magyarországi Rendeletek Tára, Tizenharmadik folyam, Kiadja a Magyar Királyi Belügyministerium, Budapest.

60.***, (1923), Constituția României din 1923 - Romanian Constitution from 1923, Monitorul Oficial al României nr. 282/29 mar. 1923, http://www.cdep.ro/pls/legis/legis_pck.htp_act_text?idt=1517

61.***, (1924), Decret nr. 2.294 din 3 iulie 1924 privind Legea Minelor - Decree on the Mining Low from 1924, Monitorul Oficial al României nr. 134 din 4 iulie 1924, http://www.monitoruljuridic.ro/act/decret-nr-2-294-din-3-iulie-1924privind-legea-minelor-emitent-parlamentul-publicat-n-monitorul-oficial-nr27481.html

62.**, (1948), Lege $n r .119$ din 11 iunie 1948 pentru naționalizarea întreprinderilor industriale, bancare, de asigurări, miniere și de transport, Monitorul Oficial al României nr. 133 bis/11 iun. 1948, http://www.cdep.ro/pls/legis/legis_pck.htp_act_text?idt=1575 